\title{
Extractor Device
}

National Cancer Institute

\section{Source}

National Cancer Institute. Extractor Device. NCI Thesaurus. Code C49945.

A device designed to remove or separate a material or object from some other material or object. 